\title{
Capturing the dynamics in benthic structures: environmental effects on morphology in the macroalgal genera Halimeda and Dictyota
}

\author{
Aletta T. Yñiguez ${ }^{1,2, *}$, John W. McManus ${ }^{1}$, Ligia Collado-Vides ${ }^{3}$ \\ ${ }^{1}$ Coral Reef Ecology and Management (CREM) Laboratory/Division of Marine Biology and Fisheries/National Center \\ for Coral Reef Research (NCORE), Rosenstiel School of Marine and Atmospheric Science, University of Miami, \\ 4600 Rickenbacker Causeway, Key Biscayne, Florida 33149, USA \\ ${ }^{2}$ Marine Science Institute, University of the Philippines, Velasquez St., Diliman, Quezon City 1101, Philippines \\ ${ }^{3}$ Department of Biology, and Southeast Environmental Research Center, Florida International University, \\ 11200 SW 8th Street, OE 167, Miami, Florida 33199, USA
}

\begin{abstract}
Macroalgae are modular organisms that can express different morphologies depending on the environment to which they are exposed. Their growth under varying light, temperature, and nutrient regimes, interacting with disturbance factors such as herbivory and hydrodynamics, leads to particular morphological types. The present study illustrates the potential of using morphological variations of benthic modular and/or clonal organisms as indicators of the factors and processes influencing them in their particular location. The morphogenetic agent-based model SPREAD (spatially explicit reef algae dynamics) was used to determine the range of potential morphological types in 3 dominant macroalgal species (Halimeda tuna, H. opuntia, and a species of Dictyota) in the Florida Reef Tract. Simulations of growth under a range of light, nutrient, and disturbance conditions similarly found at inshore patch and offshore bank reefs led to 6 potential morphological types for $H$. tuna, 2 for $H$. opuntia, and 3 for a species of Dictyota. From these potential sets derived from the model, we observed that particular morphological types corresponded to the morphologies found in the 2 reef habitat types. The simulated conditions that led to the formation of these morphologies in the model were similar to the environmental conditions at these sites. In addition to relating combinations of environmental and disturbance factors to macroalgal growth morphologies, the present study provides insights into the differing life-history strategies among the species, and the adaptive value of plasticity expressed by these macroalgae. The morphologies of the successful fragmenters $H$. opuntia and a generalized species of Dictyota were more influenced by disturbance. On the other hand, the morphology of the less successful fragmenter $H$. tuna was strongly influenced by the growth factors of light and nutrients.
\end{abstract}

KEY WORDS: Agent-based modeling $\cdot$ Macroalgae $\cdot$ Coral reef $\cdot$ Florida Keys · Morphology · Halimeda spp. · Dictyota

Resale or republication not permitted without written consent of the publisher

\section{INTRODUCTION}

Modular and/or clonal organisms, such as macroalgae, can have highly plastic morphologies, indeterminate growth, greater importance of size than age in their life histories, and capacity for asexual reproduction (Jackson \& Coates 1986). These characteristics have been investigated primarily in terrestrial plants and corals within the past several decades. These stud- ies have shown that the modules making up the bodies of these organisms, and the ramets that can break off to form new individuals, have their own dynamics analogous to the population dynamics of individuals, and that these strongly influence the pattern of vertical and horizontal capture of space (Bell \& Tomlinson 1980, Harper 1985, Halle 1986, Cain et al. 1996). Many species of marine macroalgae found in coral reefs display differential levels of plasticity in their morpholo- 
gies, similar to many other plants and macroalgae in other systems (Bradshaw 1965, Monro et al. 2007). Their modular construction is one source of their morphological phenotypic plasticity (Halle 1986). A modular organism's body is built up by the iteration of 1 or more distinct units, i.e. modules (Tuomi \& Vuorisalo 1989). In terrestrial plants, these modules generally consist of leaves, stems, and roots. It has been shown that these plant modules are able to react, independently of the whole plant, to their local environment (Sutherland \& Stillman 1988, de Kroon et al. 2005). Roots, for example can 'forage' for nutrients: in lownutrient patches, the filamentous roots lengthen, whereas under high-nutrient conditions, they branch more in order to exploit the good patch (Lovett-Doust 1981, de Kroon \& Hutchings 1995). A continuum of forms can thus be found between 2 extreme strategies: the 'phalanx' or consolidating compact strategy and the 'guerilla' or explorer spreading strategy (sensu Lovett-Doust 1981). Aquatic flora are just as capable of such variations in form. By adjusting size, shape, and resource allocation, macroalgae have a distinctive response to light quality and quantity in which elongated forms (guerilla growth form) are present in lowlight environments contrasting with compact forms (phalanx-type) (Lovett-Doust 1981, Collado-Vides 2002, Monro \& Poore 2004, 2005, Monro et al. 2007). In these modular organisms, the ability to modify their morphology may function as a mechanism to respond to a changing environment; therefore, plasticity has been considered an important adaptive mechanism by which organisms deal with the environmental challenges to their survival (Bradshaw 1965, Bell \& Tomlinson 1980, Lovett-Doust 1981, Harper 1985, Hutchings 1988, Hutchings \& Wijesinghe 1997, de Kroon et al. 2005, Monro \& Poore 2005).

Macroalgae need certain water temperatures for rapid growth and reproduction, sufficient light for high levels of photosynthesis without photo-inhibition, and enough water movement to allow for an optimal amount of nutrients to be taken in, but not strong enough to cause damage or uprooting. There should also be nothing around that eats it or grows on it. However, it is quite rare that all those conditions exist at one time and area, and like all other organisms, there are trade-offs to be made between growing and reproducing versus avoiding injury and death. For modular organisms, such trade-offs can be deciphered from their growth form in conjunction with knowledge about the environment they live in. It has been proposed that to maximize productivity, thin and wide thallus forms that have high surface area to volume ratio are preferred (Littler \& Littler 1980, Hay 1986). However, this growth preference is constrained by forces that detach parts or the whole alga (Lubchenco
\& Gaines 1981, Koehl 1986). There have been a relatively large number of studies investigating the effect of the trade-off between obtaining light and the potential damage that water motion can cause. In temperate species such as kelp, many morphological traits seem to be strongly affected by these 2 factors (Koehl \& Wainwright 1977, Koehl \& Alberte 1988, Carrington 1990). There are only a few studies that have looked at these aspects of macroalgal growth in tropical ecosystems. For example, Collado-Vides (2002) demonstrated that differences in the morphology of Caulerpa prolifera in a coral reef lagoon in Puerto Morelos, Mexico, were related to light and possibly variation in water motion. On the disturbance or mortality side, decreased herbivory was shown by Lewis et al. (1987) to lead to a drastic change in the morphology of Padina jamaicensis from a prostrate turf growth form to a foliose upright one. A study by Hay (1981) illustrated that trade-offs between obtaining light and avoiding grazing led to shifts between upright and compact growth forms among several macroalgal species, including Halimeda opuntia and Dictyota bartayresi.

Our study area, the Florida Reef Tract, has a high cover of macroalgae (Chiappone \& Sullivan 1997, Lirman \& Biber 2000), and similar to many other coral reef ecosystems in the Caribbean, this reef system has experienced a drastic decline in the cover of reefbuilding corals within the last 3 decades (Porter et al. 2002, Gardner et al. 2003, Beaver et al. 2006, but see Bruno et al. 2009). The dominant macroalgal species belong to 2 genera: Halimeda (Chlorophyta) and Dictyota (Heterokontophyta) (Lirman \& Biber 2000). In these reefs, macroalgae are exposed not only to 1 or 2 factors, but to a set of factors that could be playing important roles in their morphological responses, which ultimately scale up to larger scale patterns and processes (e.g. distributions and rates of spread).

Typically, studies on macroalgal morphology, as well as population and community dynamics, have investigated the effects of only 1 or 2 factors. Understanding of the complex interactions among a larger number of important growth and mortality factors with macroalgae morphologies and the potential underlying mechanisms remains a gap in our knowledge. The present study aimed to help fill in this gap by investigating the responses of the modules making up the individuals of these macroalgae to a combination of factors present in a coral reef environment, and evaluating the role of plasticity as a mechanism to balance the effects of these factors. To meet this overall goal, we wanted to determine (1) the potential (using a model) and (2) the realized (model results compared to the field) morphological plasticity in 3 dominant species of macroalgae in the Florida Keys - Halimeda tuna (Ellis and Solander) Lamouroux, H. opuntia (Linnaeus) Lamouroux, and Dictyota men- 
strualis (Hoyt) Schetter, Hörnig and Weber-Peukertand (3) the factors (light, temperature, nutrients, and disturbance) contributing to these morphologies.

\section{MATERIALS AND METHODS}

SPREAD formulation. SPREAD (spatially explicit reef algae dynamics) is a spatially explicit agent-based model wherein the basic agent is a macroalgal module. It was developed in order to explore the ecological implications of the inherent morphological plasticity of macroalgae. More details on the formulation and implementation of the model are found in Yñiguez et al. (2008). In the model, a fundamental premise is that the production of modules (the iterative units) by other modules is affected by the external conditions of light, temperature, nutrients, and availability of space. Internally, species-specific branching rules are used to capture branching characteristics (Figs. S1, S2 \& S3 in Supplement 1 available at www.int-res.com/articles/ suppl/m411p017_supp.pdf). SPREAD makes use of a 3-dimensional (3D) grid in which 1 cell is equivalent to $1 \mathrm{~cm}^{2}$ area. The bottom of this grid is the substrate and each cell row is assigned a particular depth in $1 \mathrm{~cm}$ increments. Irradiance or photosynthetically active radiation (PAR) at depth is represented using the Lambert-Beer law, parameterized with field measurements (Table 1). Modules within a particular distance can also 'shade' the growing module by decreasing the amount of light getting through. Temperature and nutrients do not vary spatially within the 3D grid, but can vary temporally depending on the scenario being run. The growth probability functions in response to light for each species of macroalgae are derived from laboratory studies (Table 2) (Yñiguez 2007). Normal probability distributions are used to represent their response to temperature, based on mean and variance values in the literature. The production of modules by each species of macroalgae in response to various nutrient levels is coarsely represented by a probability value for each of the 3 nutrient levels (low, medium, high). The parameters used for the present study are found in Tables $1 \& 2$.

Table 1. Halimeda tuna, H. opuntia and Dictyota sp. SPREAD environmental parameters used in simulations exploring the potential morphological clusters of the 3 macroalgae. SD = standard deviation; SERC-FIU = Southeast Environmental Research Center at Florida International University; na = not applicable

\begin{tabular}{|c|c|c|c|c|c|}
\hline Main factor & $\begin{array}{l}\text { Parameters } \\
\text { within factor }\end{array}$ & Description & Unit & Values used & Source \\
\hline Season & & $\begin{array}{l}1 \text { static or } 2 \text { seasons; } \\
\text { make use of seasonal } \\
\text { values where specified }\end{array}$ & na & 2 & \\
\hline Depth & & Bottom depth & $\mathrm{m}$ & 7 & \\
\hline \multirow[t]{5}{*}{ Light } & Irradiance & Surface irradiance & $\mu \mathrm{mol} \mathrm{m}{ }^{-2} \mathrm{~s}^{-1}$ & $\begin{array}{c}100,500,700,900 \\
1300,1700,2100 \\
2500,2900,3100\end{array}$ & $\begin{array}{l}\text { SEAKEYS and } \\
\text { field observations }\end{array}$ \\
\hline & Irradiance SD & Surface irradiance SD & $\mu \mathrm{mol} \mathrm{m}{ }^{-2} \mathrm{~s}^{-1}$ & $\begin{array}{c}30 \% \text { of } \\
\text { surface irradiance }\end{array}$ & Field observations \\
\hline & $\begin{array}{l}\text { Attenuation } \\
\text { coefficient }\end{array}$ & $\begin{array}{l}\text { Irradiance attenuation } \\
\text { coefficient }\end{array}$ & na & 0.26 & SERC-FIU \\
\hline & Allow shading & $\begin{array}{l}\text { If shading will } \\
\text { occur or not }\end{array}$ & Boolean & True & \\
\hline & $\begin{array}{l}\text { No. of cells affected } \\
\text { by shading }\end{array}$ & $\begin{array}{l}\text { No. of cells below } \\
\text { module that will be } \\
\text { affected by its shade }\end{array}$ & Cells & 3 & Calibrated \\
\hline \multirow[t]{2}{*}{ Temperature } & Mean temperature & & ${ }^{\circ} \mathrm{C}$ & $\begin{array}{l}\text { Summer: } 24.5-32.3^{\circ} \mathrm{C} ; \\
\text { Winter: } 6.6-27.9^{\circ} \mathrm{C}\end{array}$ & $\begin{array}{l}\text { SERC-FIU and } \\
\text { field observations }\end{array}$ \\
\hline & Temperature SD & & ${ }^{\circ} \mathrm{C}$ & $\begin{array}{l}\text { Summer: } 5.5 \% \text {; } \\
\text { Winter: } 18.90 \%\end{array}$ & $\begin{array}{l}\text { SERC-FIU and } \\
\text { field observations }\end{array}$ \\
\hline Nutrient levels & & Coarse nutrient levels & na & $\begin{array}{l}\text { 1: low } \\
\text { 2: medium } \\
\text { 3: high }\end{array}$ & Exploratory \\
\hline
\end{tabular}




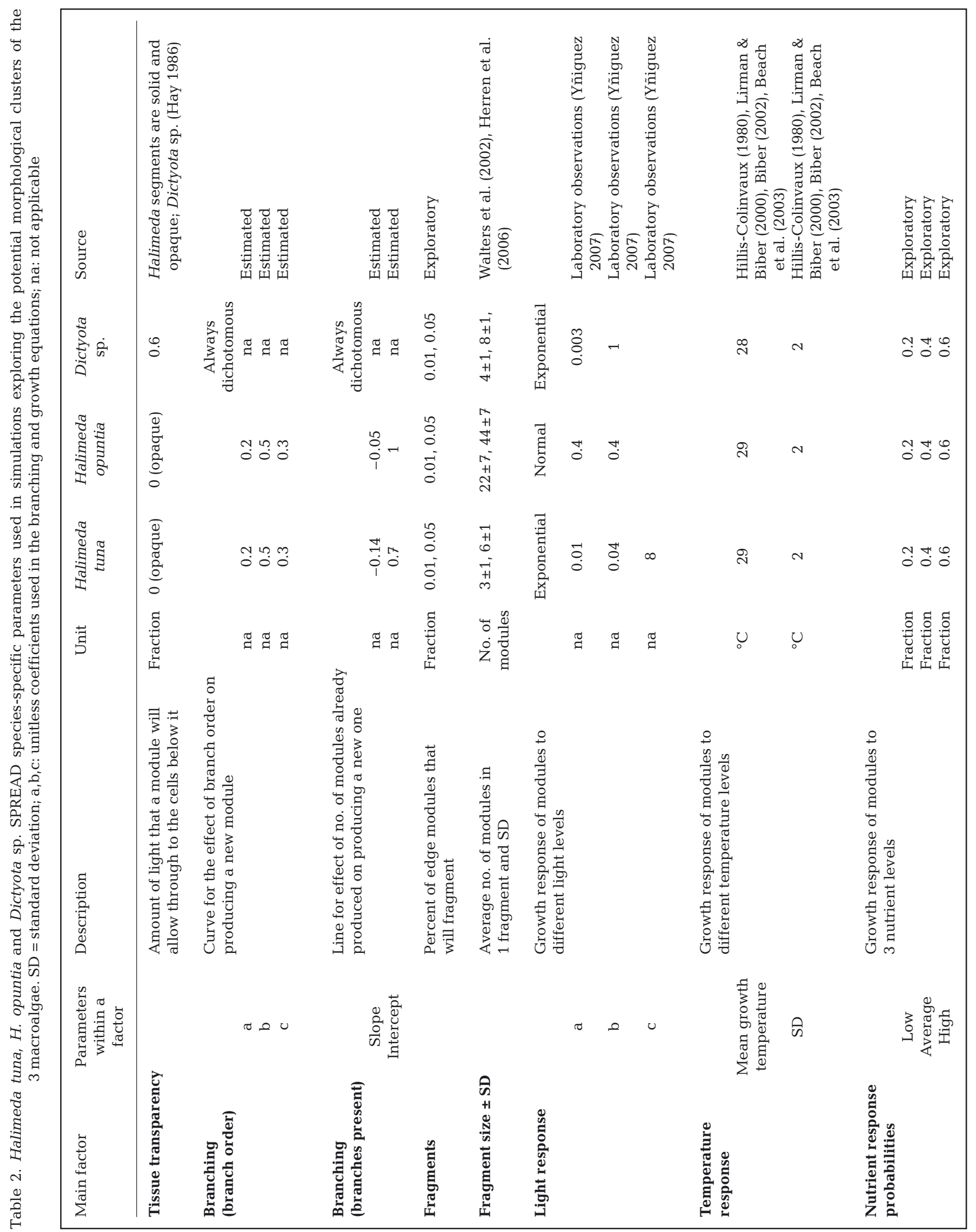


Disturbance in SPREAD is represented through fragmentation of the macroalgal modules. Simulated fragmentation occurs when algal modules are severed from the attached individual alga. It only occurs from the edges and once fragmented modules are considered lost or dead (i.e. no fragment survival and settlement). This is appropriate in the present study because only the morphology of the individual macroalga is of concern. Disturbance was distinguished into 2 types: herbivory and high water motion. Large herbivores such as fish mainly pick on macroalgae from the edges, and so herbivory effects in SPREAD were simulated via losses of edge modules at 2 levels (low and high fragmentation). High water motion from surge or currents can either uproot the whole alga or tear off more and larger fragments from the individual. SPREAD captures this through detachment of larger and more fragments or of whole individuals.

Dictyota sp. in the model does not refer to a particular species since the light-response curve was obtained from D. cervicornis (Yñiguez 2007), while the other parameter values were obtained from literature values for various Dictyota spp. as available (Table 2).

Morphometrics such as number of segments, height, and width were obtained from the virtual macroalgae in SPREAD so as to emulate how they were measured in the field, thus allowing for direct comparisons between field characteristics and those resulting from the simulations.

SPREAD was implemented using the object-oriented programming language Java, and the Mason multiagent simulation toolkit (Luke et al. 2005, http://cs. gmu.edu/ eclab/projects/mason/) as the backbone.

Model scenarios. SPREAD was parameterized with various light, temperature, and nutrient values and disturbance regimes in order to explore the space of potential morphological responses. Ten irradiance levels were used, ranging from 100 to 3100 PAR. The minimum value was based on PAR data from the SEAKEYS Fowey Rock and Molasses Reef stations in the Florida Reef Tract. The maximum value was based on PAR data obtained using a LI-COR LI-193 Spherical Underwater Quantum Sensor at the 4 study sites discussed in the section 'Fieldwork study sites and their environmental variability'. A 30\% standard deviation was used for each level, based on the variance observed empirically at the 4 study sites.

The 2 seasons of summer and winter were represented in all of the scenarios run. The range of temperatures for the summer season was 24.5 to $32.3^{\circ} \mathrm{C}$, and for the winter season it was 6.6 to $27.9^{\circ} \mathrm{C}$. These ranges were based on the 1995 to 2004 data set by the Southeast Environmental Research Center (SERC) at Florida International University for their sites closest to the 4 study sites, as well as temperature data obtained directly using a YSI multi-parameter probe. During each discrete time step in the model (equivalent to a day), a temperature value was randomly chosen from the appropriate seasonal range, using a uniform distribution.

In the simulations, each irradiance level was crossed with each of the 3 nutrient levels and 3 disturbance regimes of 0.01 and $0.05 \%$ fragmentation, and $0.05 \%$ fragmentation with larger fragment sizes. Disturbance regimes represent low $(0.01 \%)$ and high $(0.05 \%)$ disturbance that simulates more of an herbivory effect because fragments are taken only from edges. The higher disturbance with larger fragment sizes simulates more of the effect of high water motion. All of these scenarios were run for the 3 macroalgal species separately. Ten individuals of a species were randomly distributed in the grid, and the model was run for 1000 d. Data from the average of 50 runs were used and the same morphometrics obtained from the field were also gathered from the model.

Fieldwork study sites and their environmental variability. Four sites in the Florida Keys were used for the present study (Fig. 1), which represented distinct environmental conditions. They included 2 inshore patch reefs, Coral Gardens (24 $\left.50.157^{\prime} \mathrm{N}, 80^{\circ} 43.657^{\prime} \mathrm{W}\right)$ and Cheeca Patch $\left(24^{\circ} 53.826^{\prime} \mathrm{N}, 80^{\circ} 36.948^{\prime} \mathrm{W}\right)$, and 2 offshore bank reefs, Little Grecian $\left(25^{\circ} 07.140^{\prime} \mathrm{N}\right.$, $\left.80^{\circ} 18.020^{\prime} \mathrm{W}\right)$ and French Reef $\left(25^{\circ} 02.022^{\prime} \mathrm{N}\right.$, $\left.80^{\circ} 20.997^{\prime} \mathrm{W}\right)$. The latter 2 sites were located seaward and were more exposed to the predominantly ESE winds, as well as influenced by the Florida Current (Haus et al. 2004), while the inshore sites were more protected by the outer reef tract. Paddack (2005) compared grazing intensity of herbivores on macroalgae in the inshore versus offshore reefs in the Florida Keys and showed that it was higher in the offshore reef tract. The inshore sites thus appear to be less exposed to the 2 types of disturbances considered here relative to the offshore ones.

The 4 sites did not vary in the surface irradiance at noon that they received. However, irradiance at substrate level varied when this was calculated using overall average surface irradiance (2071.8910 $\mu \mathrm{mol}$ quanta $\mathrm{m}^{-2} \mathrm{~s}^{-1}$ ), site-specific depths, and average attenuation coefficients $(0.26$ for the offshore reef area and 0.34 for the inshore reef areas close to Hawk Channel). These values were obtained from the longterm water-quality monitoring data of the SERC. The 2 inshore patch reefs (both $3.7 \mathrm{~m}$ in depth) on average experienced lower light conditions at depth compared to the offshore bank reef sites Little Grecian (3.2 m deep) and French Reef (5.7 m deep) (Fig. 2), which was much deeper than the inshore reefs. The lower light values were due to these patch reefs being significantly more turbid (Boyer \& Jones 2004). In terms of nutrient conditions, SERC obtained distinct water 


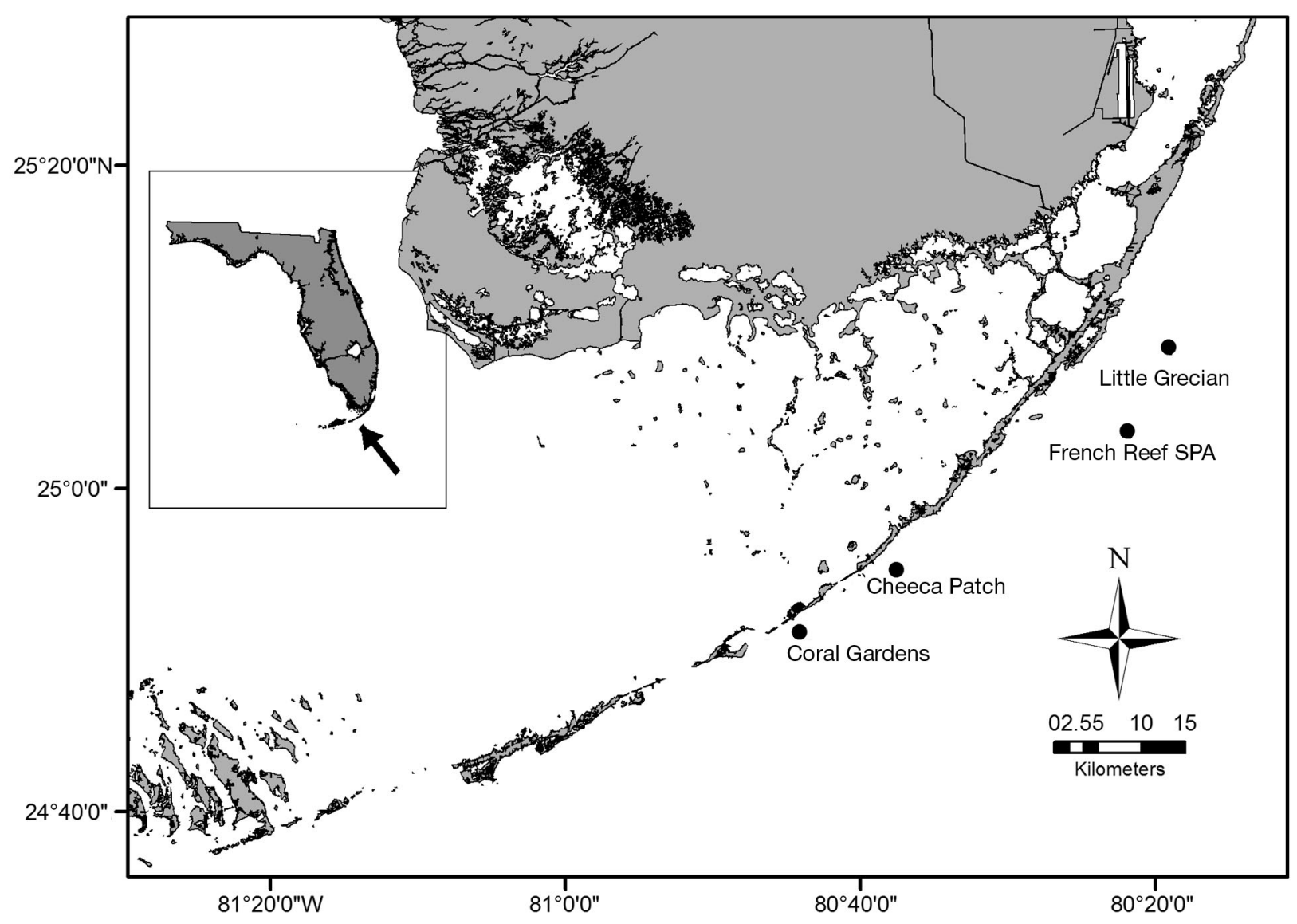

Fig. 1. Study sites in the Florida Keys Reef Tract

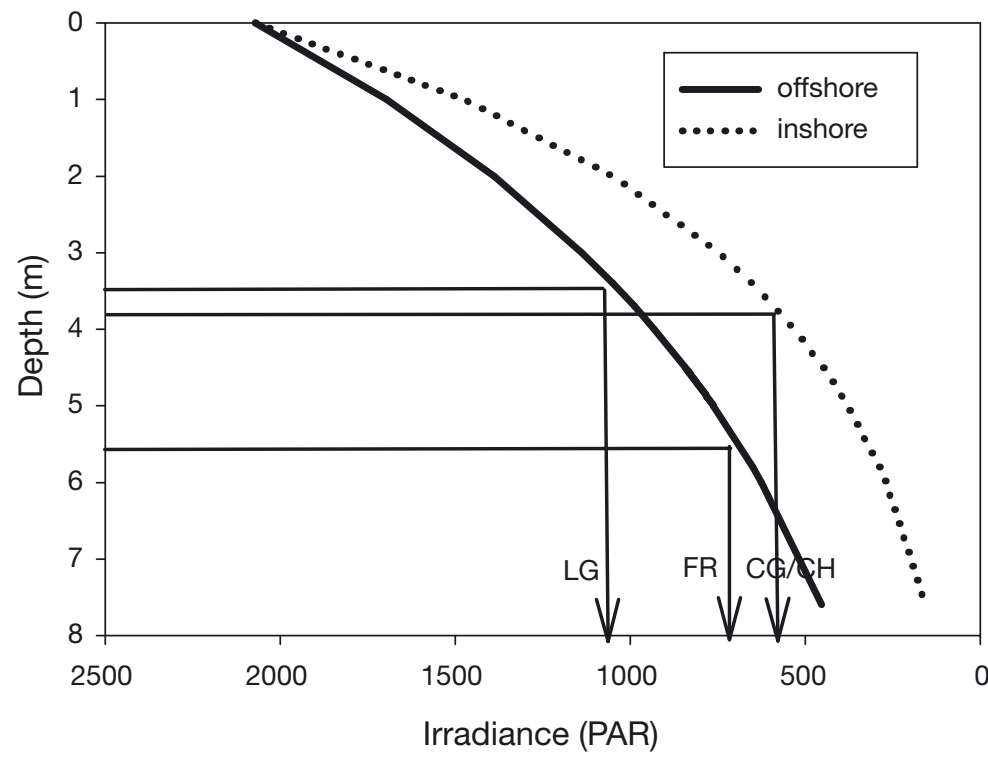

Fig. 2. Irradiance levels at the 4 study sites at the depths sampled for the morphometric surveys. Irradiance at depth was calculated using the Lambert-Beer law, applying attenuation coefficients from SERC data. Surface irradiance did not differ between the sites. Average attenuation coefficients for inshore and offshore sites were used. LG = Little Grecian, FR = French Reef, $\mathrm{CG}=$ Coral Gardens, $\mathrm{CH}=$ Cheeca Patch quality clusters out of their extensive sites throughout the Florida Keys National Marine Sanctuary (Boyer \& Jones 2004). Based on their classification, Coral Gardens and Cheeca Patch are included in either Cluster 5 or 6 , which have relatively high nutrient levels, particularly for dissolved inorganic nitrogen (DIN). In contrast, the offshore reef sites, which were all included in Cluster 3, had the lowest nutrient concentrations.

Morphometric surveys. The sites were surveyed during the summer days of September 18 and 19, 2006 when growth is highest for all 3 macroalgal species. For each site, the morphometrics of Halimeda tuna, H. opuntia, and Dictyota menstrualis were obtained. Separate surveys were done for each species where $0.5 \mathrm{~m}^{2}$ quadrats were haphazardly deployed, taking care not to include closely adjacent quadrats. Up to 10 individuals or patches of the species being surveyed were randomly chosen and measured. For $H$. tuna, data included the 'number of segments' category 
(categories in bins of 5 were used, e.g. $1=1$ to 5 segments, $2=6$ to 10 segments, and so on), number of axes (defined as the number of branches within 3 segments of the bottom-most segment), height, and width. It was difficult to determine individuals for $H$. opuntia and D. menstrualis, both of which grew in tangled clumps. For these 2 species, patches were delineated by following distinguishable boundaries. The following data were measured: height, width, and density category (1: sparse, 2: low density, 3: moderately dense, 4: very dense).

Statistical analysis. Model results - cluster analysis and canonical correspondence analysis (CCA): K-means cluster analysis in SPSS was used to differentiate distinct morphological forms that resulted from the various scenarios run with SPREAD. This method minimizes the variation within a cluster and maximizes variation between clusters. Cluster analyses were run using standardized values of the number of segments, height, width, and height:width ratio from all the scenarios. The height:width ratio was used to give an indication of the shape of the macroalgae. A value of 1 is equivalent to a hemispherical shape, values $>1$ point to uprightness, and values $<1$ indicate a flat form. Separate cluster analyses were conducted for each species using from 2 to 8 as the number of clusters, and the number of clusters that resulted in distinct, non-redundant forms was utilized.

CCA using the Vegan package in $\mathrm{R}$ was employed to distinguish the environmental conditions influencing the variation in morphologies emerging from the simulations.

Field data-principal components analysis (PCA) and multivariate analysis of variance (MANOVA): The morphometrics gathered from the field study were analyzed using PCA in order to condense the information in these morphometrics and their co-variances. The data were first transformed to natural logs in order to conform to the assumptions of PCA. Eigenvalues that were $\geq 0.32$ were extracted, following Haring \& Carpenter (2007). The components were rotated to simplify interpretation using the varimax method, which orthogonally rotates the components to minimize the number of variables with high loadings for each component (SPSS 15.0 for Windows). The first 2 principal components representing the condensed morphometric information were then subjected to MANOVA to determine differences between the study sites. If there was a difference, Tukey's post hoc test was employed to determine the specific site differences. Details of the statistical results from these analyses can be found in Tables S1 \& S2 in Supplement 1.

Comparison of model and field results: The morphometrics of the clusters derived from the model and the same metrics from each of the study sites were compared both visually and using PCA in order to qualitatively determine the similarities of the model and field morphological forms.

\section{RESULTS}

\section{Model results}

In order to obtain the potential morphologies of the 3 macroalgal species, we ran the model SPREAD using a range of realistic environmental conditions. Next, we used cluster analysis on the resulting morphometrics to distinguish between the morphological types. The effect of environmental conditions on the morphometrics were then investigated using CCA.

\section{Halimeda tuna}

There were 6 distinct clusters or morphological types for this species (Table 3, Fig. 3). Table 3 lists the detailed types, their forms and the conditions under which each is found, while Fig. 3 shows the actual model representations. Four were relatively small with shapes ranging from very flat to very upright. Two morphologies were larger, where 1 was more hemispherical than the other. Based on the results of the CCA (Fig. 4A), irradiance had the largest influence on the morphological clusters formed, followed by mortality (through fragmentation) and nutrient levels. The largest and most upright morphology of Cluster 1 (HtLU) was found only under low-light, high-nutrient, and low-fragmentation conditions. The other large cluster (Cluster 2, HtLH) was formed under high-light and relatively higher nutrient levels. The 4 clusters which contained the smaller-sized morphologies were found under varying light conditions, but mainly low to mid-level nutrient and higher fragmentation conditions. The upright forms were found more under lower irradiance levels compared to the hemispherical and wide forms, and also varying fragmentation conditions.

The larger morphologies (Clusters 1 and 2) were formed under relatively higher nutrient and low fragmentation conditions. The shapes of Halimeda tuna appeared to be controlled more by light: more upright forms were seen in lower-light conditions, shifting to hemispherical and wider shapes under higher irradiances.

\section{Halimeda opuntia}

The morphological clusters for this species were not as varied as for Halimeda tuna and the differences 
Table 3. Halimeda tuna, H. opuntia and Dictyota sp. Morphological clusters derived from the model for the 3 macroalgal species, their morphological description, and the conditions where they formed. The 'Cluster' column includes the acronym for the particular cluster (e.g. Halimeda tuna Cluster 1 large and upright is 1: HtLU)

\begin{tabular}{|c|c|c|c|}
\hline Species & Cluster & Morphology & Conditions found \\
\hline \multirow[t]{6}{*}{ Halimeda tuna } & 1: HtLU & Large and upright & $\begin{array}{l}\text { Only at low light levels; higher nutrient levels; only at low } \\
\text { mortality }\end{array}$ \\
\hline & 2: HtLH & Large and hemispherical & Higher light; higher nutrients levels; low mortality \\
\hline & 3: HtSH & Small and hemispherical & $\begin{array}{l}\text { Mid-light levels; lower nutrient levels; high mortality levels } \\
\text { primarily with small fragments especially at nutrient levels } 2 \\
\text { and } 3\end{array}$ \\
\hline & 4: HtSU & Small and upright & $\begin{array}{l}\text { Low light; middle nutrient levels; high mortality (both small } \\
\text { and large fragments) }\end{array}$ \\
\hline & 5: HtSVU & Small and very upright & $\begin{array}{l}\text { Mid-light levels; lower nutrient levels; high mortality (small } \\
\text { fragments mainly) }\end{array}$ \\
\hline & 6: HtSW & Small and wide & $\begin{array}{l}\text { High light; mid-nutrient levels; high mortality with large } \\
\text { fragments }\end{array}$ \\
\hline \multirow[t]{2}{*}{ Halimeda opuntia } & 1: HoLLU & Large and less upright & $\begin{array}{l}\text { All light and nutrient levels; low mortality or high mortality } \\
\text { with large fragments }\end{array}$ \\
\hline & 2: HoSU & Small and upright & All light and nutrient levels; high mortality \\
\hline \multirow[t]{3}{*}{ Dictyota sp. } & 1: DSU & Small and upright & Mid-level light and nutrients; only at high mortality \\
\hline & 2: DSH & Small and hemispherical & $\begin{array}{l}\text { Mid-level light; low nutrients; high mortality (small and large } \\
\text { fragments) }\end{array}$ \\
\hline & 3: DLH & Large and hemispherical & Mid-to high light; high nutrient levels; low mortality \\
\hline
\end{tabular}

1

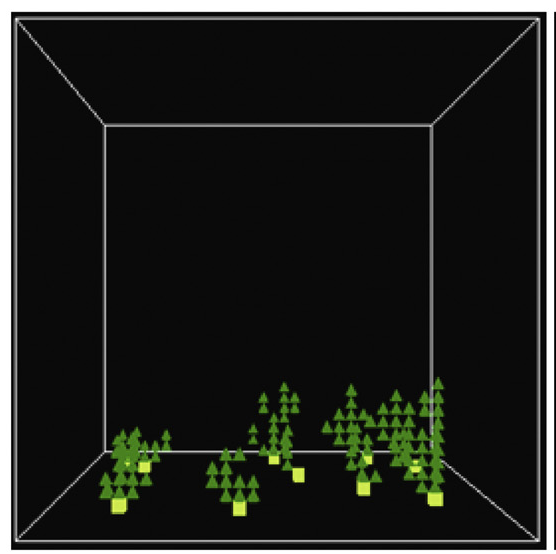

4

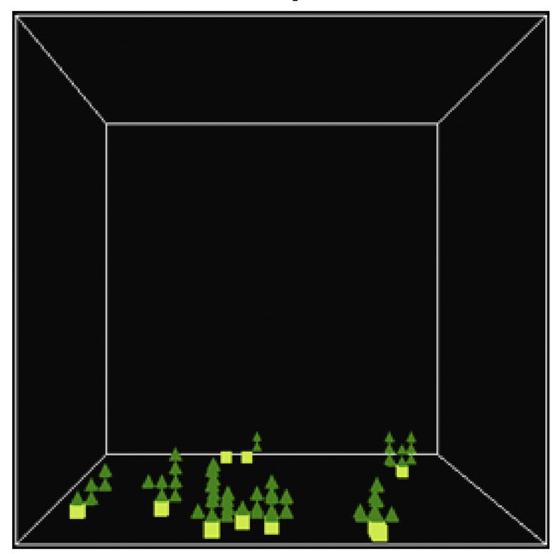

2

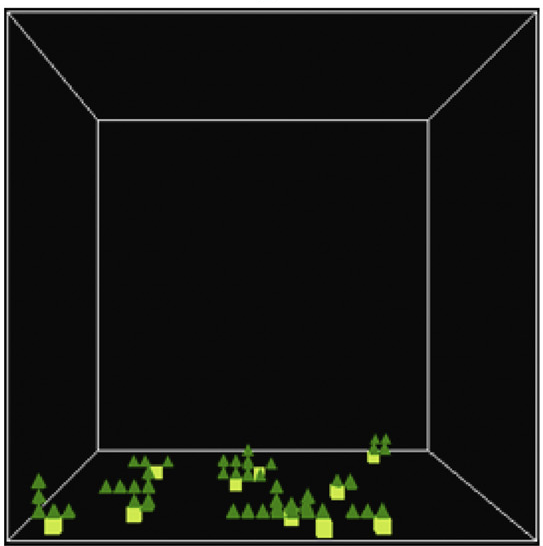

5

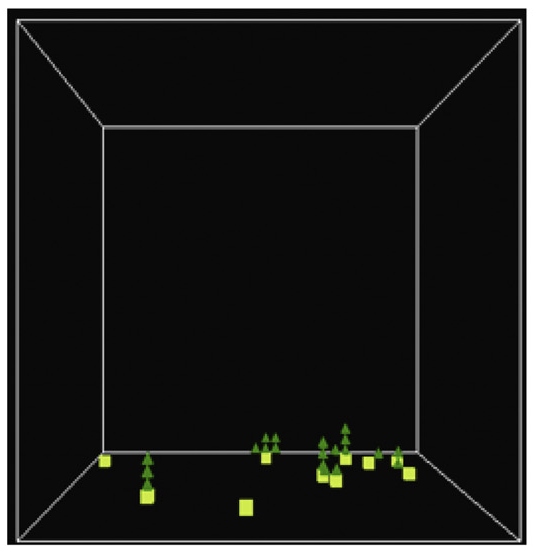

3

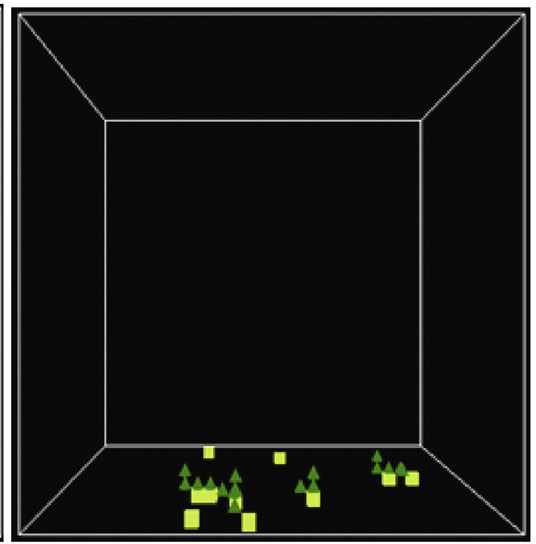

6

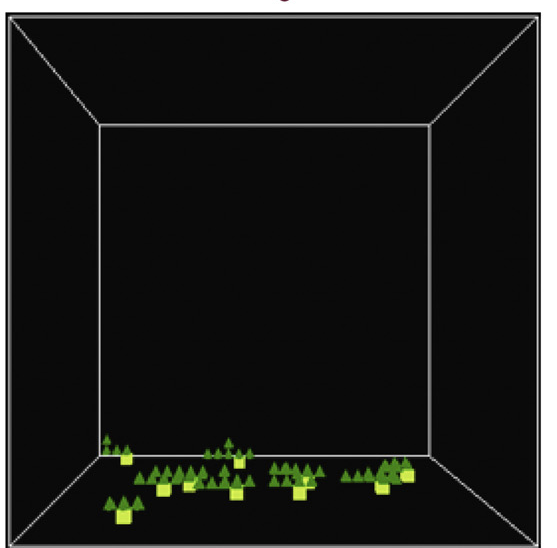

Fig. 3. Halimeda tuna. Morphological clusters derived from SPREAD. Table 3 details the characteristics of these clusters. Illustrations of the 2 other macroalgae can be found in Fig. S4 in Supplement 1 

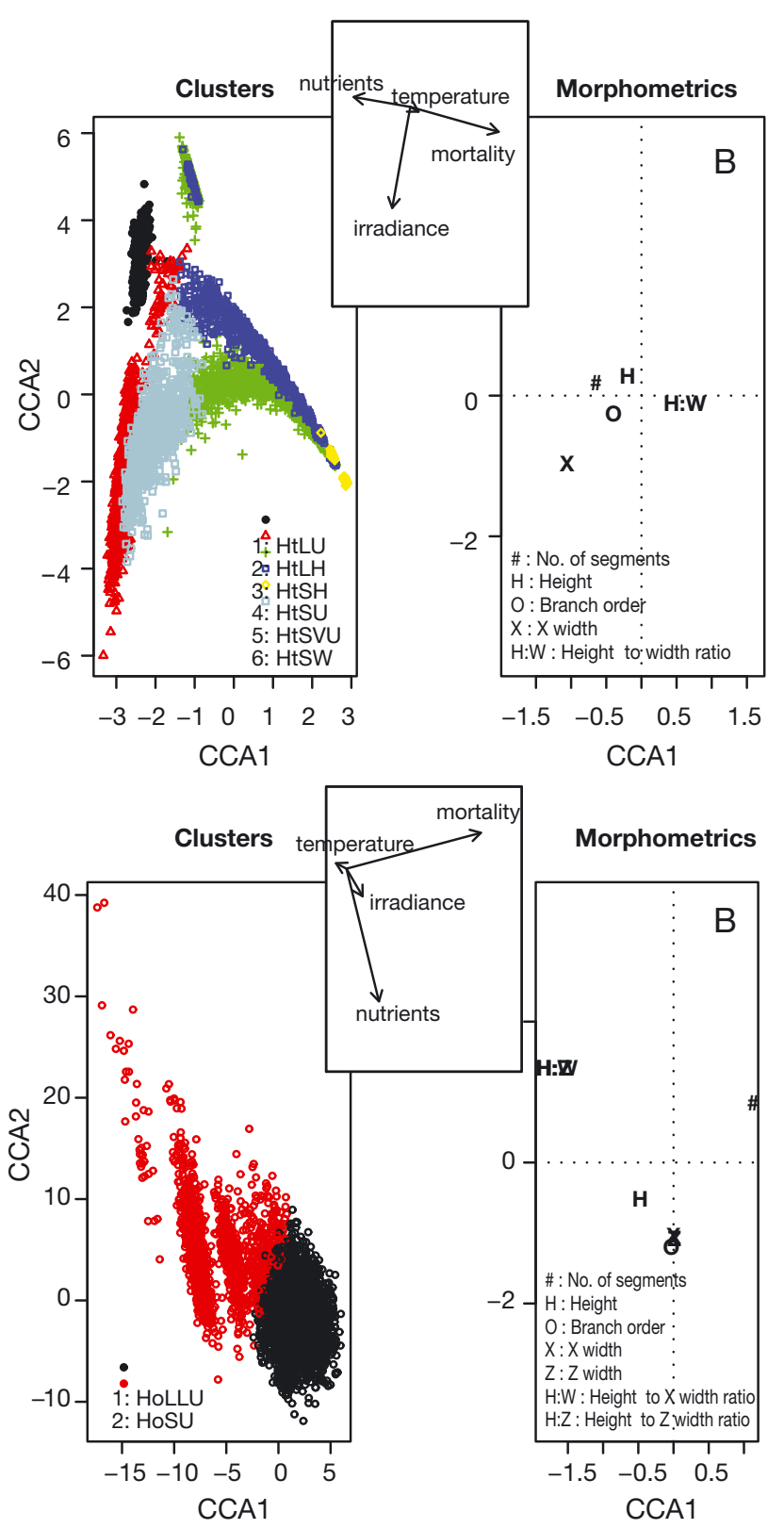

between clusters were mainly due to size rather than size and shape. Two clusters were used to represent the main forms observed: small and upright, and large and less upright (Table 3, Fig. S4 in Supplement 1). The larger form was tending towards the hemispherical shape, but was still taller than wide.

The primary factor distinguishing the 2 clusters was the fragmentation level (Fig. 4B), wherein the small and upright form was found under the extremes of low fragmentation and high fragmentation with large fragments, while the large and upright form was seen primarily under high fragmentation but smaller fragment sizes. Cluster 1 tended to form in higher light and nutrient conditions compared to Cluster 2.

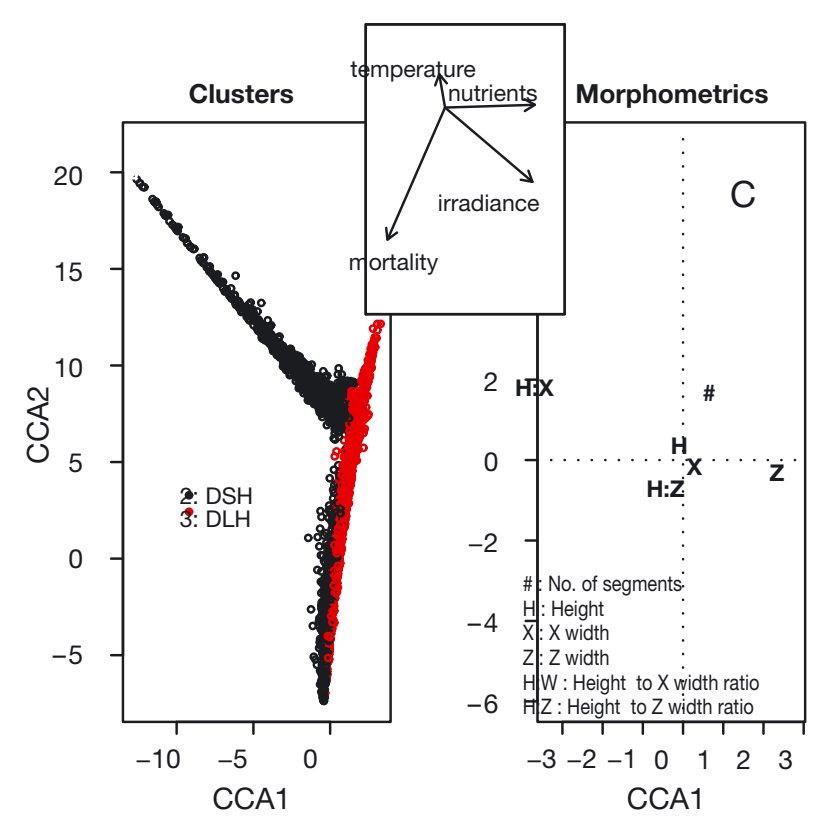

Fig. 4. (A) Halimeda tuna, (B) H. opuntia, and (C) Dictyota sp. Biplots of canonical correspondence analyses (CCA) results showing the scatter of the morphological (clusters) forms and the contributing morphometrics (morphometrics) relative to the environmental factors (smaller panel in the middle). See Table 3 for symbol abbreviations

\section{Dictyota sp.}

There were 3 distinct morphological clusters observed for Dictyota sp. Two clusters were small and either upright or hemispherical in shape, while the third cluster was large and hemispherical (Table 3, Fig. S4 in Supplement 1).

The small and very upright form, Cluster 1 or DSU, was very restricted (seen only 6 times out of 4503 model runs), and was only found under nutrient level 2 at a mid-irradiance level and high fragmentation (larger fragments). The hemispherical forms (DSH and DLH) occurred under different but higher levels of irradiance, and different nutrient levels (Fig. 4C). The 
smaller form (DSH) was found under relatively lower light levels and lower nutrient and higher fragmentation conditions (both normal and larger fragment sizes) compared to the larger form (DLH).

\section{Field results}

We also obtained real morphometrics of the 3 macroalgal species from actual reefs in the Florida Keys. Using PCA, we found that there were distinct differences in the size and shape of the 3 macroalgal species among the 4 sites, particularly between the offshore bank and inshore patch reef sites.

\section{Halimeda tuna}

The first 2 principal components explained 42 and $21 \%$ of the variation in the morphometrics of Halimeda tuna from the 4 sites, respectively. The first principal component (PC1) was strongly correlated to width, height, and number of segments, while the second (PC2) was strongly correlated to the height:width ratio (Table 4). PC1 seems to differentiate based on size, while PC2 is related more to the shape. MANOVA and post hoc tests showed that there was a significant difference between inshore and offshore sites in the 2 component loadings. H. tuna in the 2 inshore patch reef sites (Coral Gardens and Cheeca Patch) were larger (had more segments, were taller and wider) and more upright in form than the populations found in the offshore spur and groove sites (French Reef and Little Grecian). The $H$. tuna populations in the offshore spur and groove reefs had height:width ratios closer to 1 and were more hemispherical in shape.

Table 4. Halimeda tuna, H. opuntia and Dictyota menstrualis. Summary of the 2 primary principal component loading scores for the morphometrics of the 3 species measured at the 4 field sites

\begin{tabular}{|lccc|}
\hline Species & Morphometric & $\begin{array}{c}\text { Principal } \\
\text { component } 1\end{array}$ & $\begin{array}{c}\text { Principal } \\
\text { component 2 }\end{array}$ \\
\hline Halimeda tuna & No. of segments & 0.898 & -0.114 \\
& Height & 0.910 & 0.355 \\
& Width & 0.912 & -0.333 \\
& Number of axes & 0.211 & -0.098 \\
& Height:width ratio & -0.058 & 0.992 \\
Halimeda opuntia & Epiphyte load & 0.170 & 0.037 \\
& Height & 0.078 & 0.996 \\
& Width & -0.742 & 0.671 \\
Dictyota menstrualis & Height:width ratio & 0.991 & 0.126 \\
& Density & -0.030 & -0.037 \\
& Height & -0.027 & 0.980 \\
& Width & 0.882 & 0.323 \\
& Height:width ratio & -0.926 & 0.304 \\
& Density & 0.338 & 0.215 \\
\hline
\end{tabular}

\section{Halimeda opuntia}

In total, $74 \%$ of the variation in the morphometrics of Halimeda opuntia was explained by PC1 (38\%) and PC2 (36\%). PC1 was highly correlated to the height: width ratio or the shape of the macroalgae, while PC2 was correlated to the size metrics, height, and width (Table 4). MANOVA and post hoc tests separated out differences in the morphologies between sites. The $H$. opuntia in the 2 patch reefs had significantly flatter shapes (low height:width) compared to those in French Reef. Little Grecian was in the middle of these 2 extremes. However, the inshore patch reefs had significantly larger $H$. opuntia than the offshore spur and groove reefs.

\section{Dictyota menstrualis}

The first 2 principal components accounted for 44 and $30 \%$ of the variation in the morphometrics of Dictyota menstrualis. PC1 was highly correlated to the shape metrics of height:width, as well as width, while PC2 was highly correlated with height (Table 4). Once again, MANOVA and post hoc tests of PC1 and PC2 highlighted the site differences. Coral Gardens and Cheeca Patch had populations of $D$. menstrualis that differed significantly from those at French Reef and Little Grecian in their shape-related PC1 values. $D$. menstrualis in the 2 patch reefs were very wide and flat. For the height- or size-related second PC, Cheeca Patch was on one side of the spectrum as the largest and Little Grecian on the opposite side. French Reef and Coral Gardens were in the middle.

\section{Comparing model-derived and observed results}

The distinct morphologies of the 3 species in the real-world study sites could be matched to the independently-derived morphological clusters in SPREAD (Figs. 5, $6 \&$ 7). The environments where these clusters occurred in the model (Table 3) also paralleled the observed environments in the actual reefs. PCA illustrated that the macroalgae model morphologies coincided with their real-world analogues (Figs. 5B, 6B \& 7B). However, the variations of the latter were quite large and could not be precisely ascribed to particular clusters just by this analysis. The plots of the morpho- 

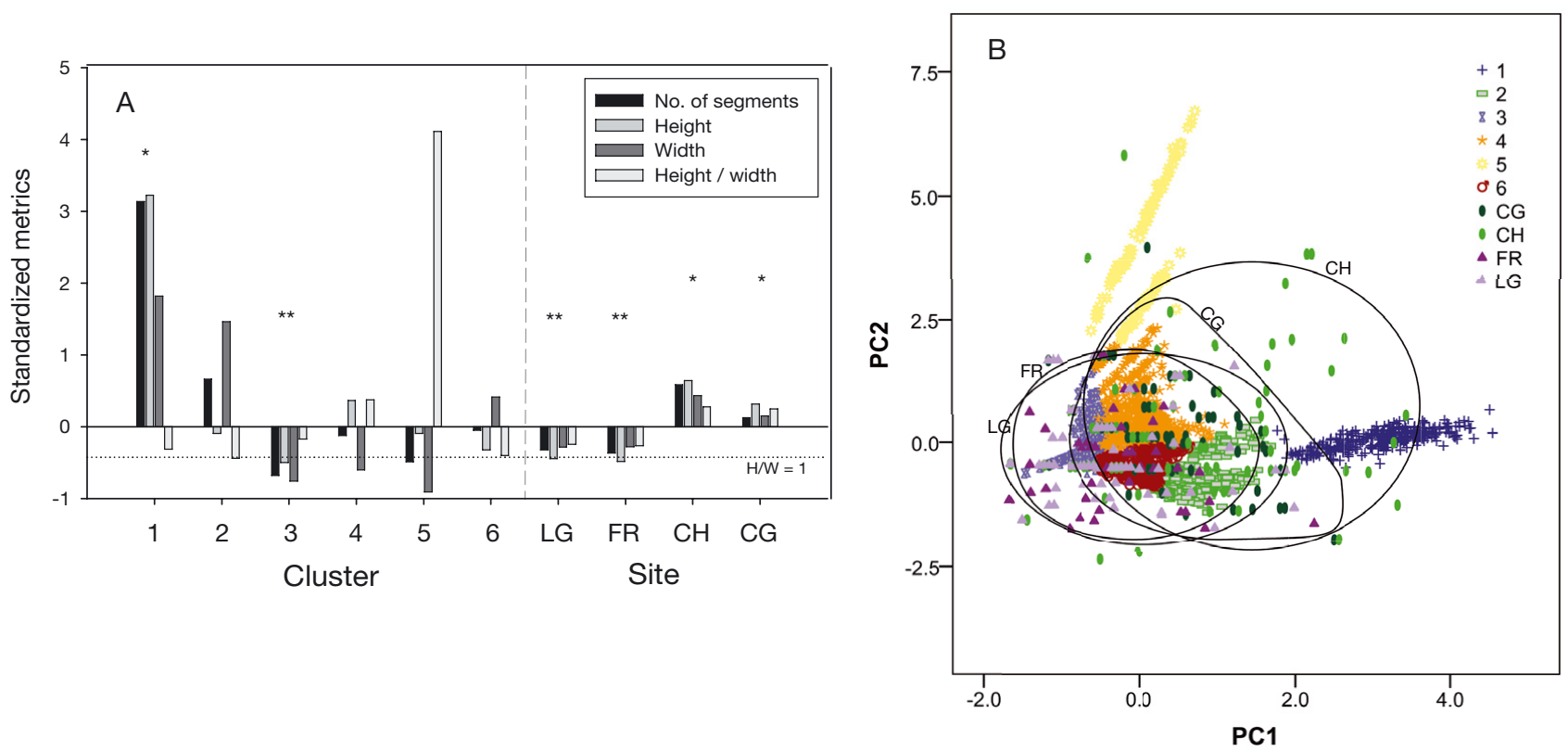

Fig. 5. Halimeda tuna. (A) Standardized morphometrics for the model-derived clusters and the study sites; (B) principal components (PC) analysis of model and field morphometrics. In (A), the dotted line denotes height:width ratio $=1$. Similar asterisks denote qualitatively similar morphologies between the model and field results. $\mathrm{LG}=$ Little Grecian, FR $=\mathrm{French} \mathrm{Reef}, \mathrm{CH}=\mathrm{Cheeca}$ Patch, $\mathrm{CG}=$ Coral Gardens
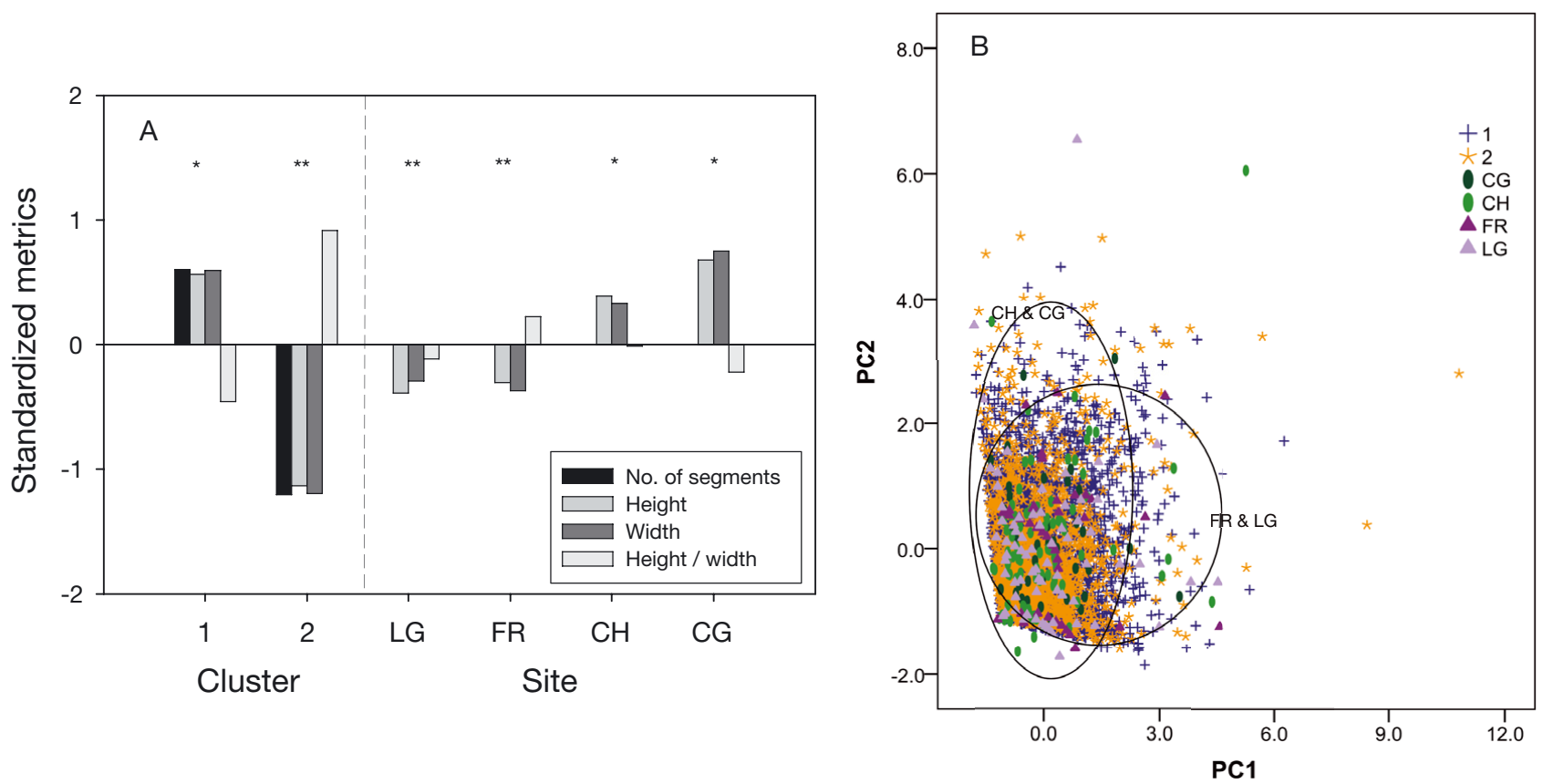

Fig. 6. Halimeda opuntia. (A) Standardized morphometrics for the model-derived clusters and the study sites; (B) principal components (PC) analysis of model and field morphometrics. In (A), similar asterisks denote qualitatively similar morphologies between the model and field results. LG $=$ Little Grecian, FR $=$ French Reef, $\mathrm{CH}=$ Cheeca Patch, CG $=$ Coral Gardens

metrics from the model and field sites more clearly distinguished the similarities between particular modelderived morphological clusters and observed forms in study sites (Figs. 5A, 6A \& 7A).
Halimeda tuna in the patch reefs were most similar in size and shape to Cluster 1 (HtLU), while the populations of the offshore reefs were most similar to Cluster 3 (HtSH). Cluster 1 (HtLU) occurred in lower-light, 

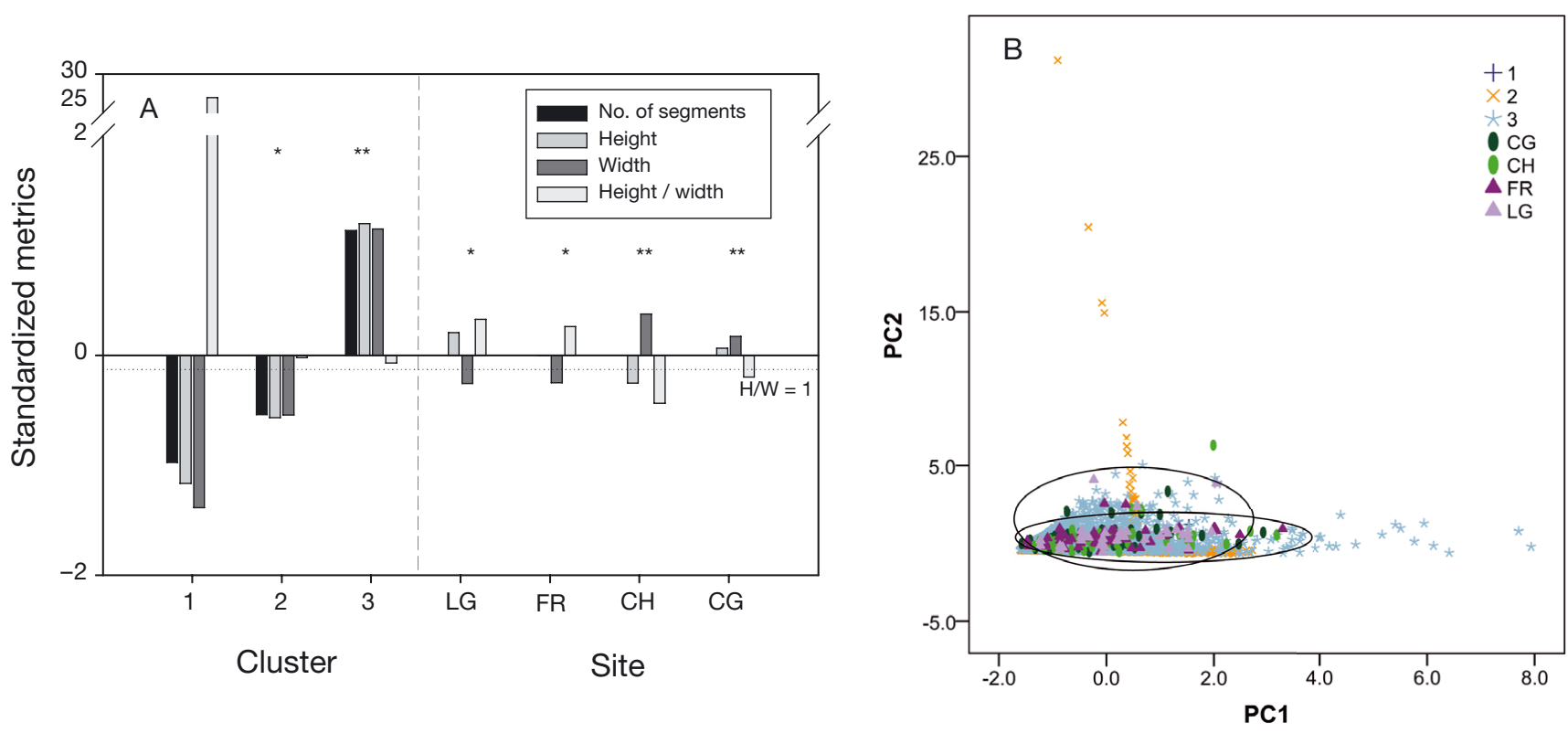

Fig. 7. Dictyota sp. (A) Standardized morphometrics for the model-derived clusters and the study sites; (B) principal components (PC) analysis of model and field morphometrics. In (A), the dotted line denotes height:width ratio $=1$. Similar asterisks denote qualitatively similar morphologies between the model and field results. $\mathrm{LG}=$ Little Grecian, $\mathrm{FR}=\mathrm{French} \mathrm{Reef}, \mathrm{CH}=\mathrm{Cheeca}$ Patch, CG = Coral Gardens

high-nutrient, and low-fragmentation conditions. Cluster 3 (HtSH) morphs occurred in high-light, lownutrient, and high-fragmentation conditions. For H. opuntia, Cluster 1 (HoLLU) corresponded to the inshore reef morphs, and the other cluster (Cluster 2, HoSU) was the most similar to the offshore reef morphs. These 2 clusters were differentiated only by fragmentation level and occurred under the same range of light and nutrient levels. Cluster 2 (DSH) in Dictyota sp. was the most similar to the offshore reef morphs, and Cluster 3 (DLH) with Cheeca Patch and Coral Garden morphs. Although DSH was found under lower light levels compared to DLH, their average values were both on the higher end and both clusters also encompassed a similar light range. The distinct differences between the 2 clusters were due to nutrients and fragmentation levels. DSH occurred in lower-nutrient and high-fragmentation conditions and DLH the opposite.

\section{DISCUSSION}

The morphological plasticity of organisms provides a unique opportunity to observe and understand the factors influencing their growth, mortality, and comparative ability to adapt to variable environments. This is especially true in modular and/or clonal immobile organisms that leave tangible evidence of the produc- tion and death of their iterating units. Distinguishable changes in the morphologies of 3 macroalgal species were observed through SPREAD as they experienced varying light, nutrient, and disturbance (through varying fragmentation effects) levels. However, the amount of morphological variation differed between the 3 species and the convergence of forms made it difficult to tease out the effects of the growth from the mortality factors in detail. Halimeda tuna had the most distinct number of categories, which also allowed for some separation of the factors responsible for them, while the morphological clusters of $H$. opuntia and Dictyota sp. converged into 2 and 3 clusters, respectively, that differed primarily only in size under a variety of scenarios.

\section{Morphological changes under ideal and less-than-ideal growth conditions}

SPREAD showed that under low fragmentation (i.e. low mortality/disturbance conditions) and optimum light and nutrient conditions, all 3 species tended to be larger-as one might expect. Halimeda tuna also grew in a more upright form under ideal conditions (Cluster 1), and when light and nutrients were higher, it became more hemispherical (Cluster 2). Hay (1981) proposed that at lower light levels, mono-layered thalli will predominate, while at higher light levels, multilay- 
ered (more upright) ones will be more abundant. Studies on the effect of light on the morphology of macroalgae also show that if light is limiting, as light decreases, the thallus module units themselves can become wider and/or the spacing between modular units becomes larger (less compact), leading to a guerilla growth form (Collado-Vides 2002, Monro \& Poore 2005, Haring \& Carpenter 2007, Monro et al. 2007). H. tuna follows a similar pattern such that there is increased compactness in shape (phalanx growth form) under higher light conditions. However, this is probably not because of their freedom from light limitation, because they have a relatively low light requirement (Beach et al. 2003) compared to the light conditions in Cluster 2 (HtLH). More likely this form is due to the photo-inhibitory effect of high light that has been shown to affect their morphology (Hader et al. 1996, Beach et al. 2003, Vroom et al. 2003).

Halimeda opuntia and Dictyota sp. did not exhibit any shift in shape similar to those of $H$. tuna when light or nutrients changed. This could be explained by the larger ranges of optimum light conditions to which H. opuntia and Dictyota sp. respond similarly. Growth experiments controlling for light in aquaria that were used to parameterize SPREAD did exhibit similar growth rates under low to high irradiance levels for these 2 species (Yñiguez 2007). The simulated Dictyota sp. did change in size under higher light and nutrient conditions, although this effect co-varied with decreased fragmentation. Beach et al. (2006) have previously observed that lower light decreased primary productivity in D. menstrualis and D. pulchella in Conch Reef, Florida Key, and that they can also be nutrientlimited and respond physiologically to nutrient enrichment. These productivity responses most likely translate to parallel increased or decreased growth.

\section{Effects of mortality through fragmentation on morphology}

Mortality, through disturbances such as herbivory and water motion, has long been recognized as a strong factor influencing macroalgal population and evolutionary dynamics (Lubchenco \& Gaines 1981, Carpenter 1986, Koehl 1986). On an individual level, these are also important factors affecting the morphology of macroalgae. Halimeda tuna did exhibit a shift in shape under increased mortality levels. Higher mortality simulating increased herbivory (high fragment pool but relatively smaller fragment sizes) resulted in smaller sizes and hemispherical shapes, leading to a phalanx growth form (Cluster 3). Lewis et al. (1987) and Diaz-Pulido et al. (2007) have shown that the brown algae Padina jamaicensis and P. boergesenii, respectively, changed from a foliose form to a prostrate turf alga when herbivore intensity increased. Hay (1986) illustrated the role of both herbivory and desiccation in favoring clumped and more hemispherical forms versus upright individuals in various macroalgal species including $H$. opuntia and Dictyota bartayresii.

Under the fragmentation conditions simulating increased disturbance, such as that from water motion, the shape of Halimeda tuna became small and wider or more prostrate. Studies on macroalgae (e.g. Mastocarpus papillatus, Fucus gardneri, Chondrus cripus) have shown that they can change their shape to smaller, more compact or prostrate forms when water motion is high (Carrington 1990, Blanchette 1997, Boller \& Carrington 2006). This shape enables them to experience less drag and thus lower the probability of being torn off from the substrate. Damage can potentially induce increased branching and/or affect directionality of growth and branching (Hay 1981, Van Alstyne 1989). Interestingly, although module mortality in SPREAD is only through fragmentation as an external force that does not induce any sort of response from the macroalgae (e.g. re-direction of growth), it is still able to reproduce known patterns in morphology attributable to mortality. Thus, it is not necessary to infer that these macroalgae respond to module mortality in any active way beyond continued growth.

Simulated Halimeda opuntia actually grew larger, though relatively less upright, with higher fragmentation levels associated with large fragment sizes (Cluster 1). However, the growth rate for this cluster was higher than that of Cluster 2 (HoSU). This is possibly due to the decrease in self-shading that can limit growth of modules in the 'understory' (Monsi et al. 1973, Harper 1985). H. opuntia is a highly branching species and its lower portions can stop growth and/or die while the upper portion continues growing (Hay 1981). As large fragments are broken off, the lower segments are then able to sequester light, grow, and branch. This is akin to pruning in terrestrial plants, wherein higher growth rates are achieved when pruning is regular. Fragmentation with smaller fragment sizes (simulating fragmentation due to herbivory) was not enough to obtain a similar effect and resulted in smaller, slower-growing forms. Fragmentation, whether with small or larger fragments, affected Dictyota sp. only by decreasing its overall size.

The concept of a trade-off in the morphology of macroalgae implies a response (at the ecological scale) to the forces acting on an individual. One of the common examples for this trade-off is the variation in the blade width of temperate macroalgae among depths and different wave exposures (Koehl \& Wainwright 1977, Koehl \& Alberte 1988, Carrington 1990, Haring $\&$ Carpenter 2007). These studies have shown that the 
macroalgae can not only actively respond to light availability but also to hydrodynamics as a disturbance factor. In SPREAD, responsiveness is through amount of module production and directionality of module production as affected by light, temperature, nutrients, and space availability, while disturbance through fragmentation is an external and random process that does not directly effect any response. Other mechanisms for responding to light and nutrients that can influence morphology of the 3 macroalgae studied are size of segments (Beach et al. 2003, Vroom et al. 2003, Smith et al. 2004) and intersegment distances (Littler \& Littler 2000 for Halimeda opuntia). Damage to the macroalgal thallus has been shown to potentially cause the growth of adventitious branches on Dictyota spp. (Gaillard et al. 1986, Cronin \& Hay 1996). Even though SPREAD does not incorporate these other potential mechanisms for morphological plasticity, it was able to capture realistic variations in the 3 species because the morphometrics used were generalized enough.

\section{Differential strength of factors influencing morphologies: a sign of differences in life-history strategies?}

The 3 species had varying morphological plasticity and responses to the growth and mortality factors. Halimeda tuna could be said to have the most plastic morphology, relative to $H$. opuntia and Dictyota sp., in terms of the morphometrics that were included in the present study. This could be due to the larger range of H. opuntia and Dictyota spp. light requirements, allowing them to grow similarly whether at lower or higher irradiance levels (Beach et al. 2006) leading to a lower plasticity response and limiting their morphological spectrum as compared with $H$. tuna. An alternative explanation is that other morphometrics that were not used in SPREAD give rise to other morphologies in these 2 species. Segment size can vary for both, as well as segment shape and intersegment distances for H. opuntia. H. opuntia are known to exhibit higher intersegment distances and smaller and tri-partite segments that grow up loosely in lower light levels (Kooistra \& Verbruggen 2005). For these 2 species, measuring density could have also provided increased distinction of morphologies.

Halimeda tuna was strongly affected by both growth (light and nutrients) and mortality or disturbance factors. This is in contrast to $H$. opuntia and Dictyota sp., which were more strongly influenced by disturbance (fragmentation leading to mortality) forces. Previous studies on $H$. tuna have shown similar shifts in morphology due to differing light and nutrient conditions (Beach et al. 1997, 2003, Vroom et al. 2003, Smith et al.
2004) but no observed variation in grazing pressure (i.e. mortality). This species appears to be sensitive not only to limited light but also high light conditions that cause photo-inhibition (Beach et al. 2003). Increased nutrient levels have also resulted in larger, more upright morphologies (Smith et al. 2004). H. opuntia and Dictyota sp. variation in size and (slightly) in shape was strongly influenced by disturbance rather than light, and for Dictyota sp. nutrients as well. Both of these species are relatively 'good' fragmenters compared to H. tuna. This mechanism potentially allows these species to persist and even spread under high disturbance conditions. H. opuntia produces large fragments that can have high survival probabilities (up to $93 \%$ ) (Walters et al. 2002). Various Dictyota species are the dominant macroalgae in the offshore reefs of the Florida Keys despite being in a high-disturbance environment. Their morphology in these sites indicates a low-nutrient and high-disturbance environment, yet they are successful in persisting and occupying the reef substrate. This is probably due to their capacity to easily produce fragments, which have almost a $100 \%$ survival probability even with small fragment sizes (Vroom 2001, Herren et al. 2006).

\section{Macroalgal morphology as indicators of environmental conditions}

At the cross-genus level, the morphologies of macroalgae can provide information about the environments in which they are found (Littler \& Littler 1980, Steneck \& Dethier 1994). These generalized groupings tend to be useful when investigating large-scale patterns, although the large variations in life histories of these different groups can obscure this information (Padilla $\&$ Allen 2000). Focusing on certain species can help give a clearer picture on the environmental factors influencing macroalgal morphologies (e.g. Hanisak et al. 1988, Benedetti-Cecchi et al. 2006).

The morphologies derived from SPREAD corresponding with those found in the study sites provided information on the gradient of environmental conditions these macroalgae were experiencing where they were located. The 2 inshore patch reefs were characterized by intermediate light levels, higher DIN concentrations, and calmer conditions (less disturbance), while the offshore bank reefs have higher light levels, lower DIN concentrations, and stronger water motion through wave action and currents. It appears that the morphometrics of Halimeda tuna can be good indicators of the conditions under which they are found: larger and more upright forms tend to be in lower-light (i.e. non-photo-inhibiting), higher-nutrient, and calmer environments (Beach et al. 2003, Vroom et al. 2003, 
Smith et al. 2004). H. opuntia and Dictyota sp. morphologies were more indicative of the disturbance conditions, whether herbivory or hydrodynamics, of their habitats.

Acknowledgments. The authors thank D. De Angelis, D. Lirman, L. Brand, P. Glynn, and F. Gayanilo for their invaluable ideas and comments during the development of this project. M. Brandt and W. Cooper provided much-needed hands-on support for the project. We are grateful for the funding provided by the Environmental Protection Agency (X-831661012 NCORE), NSF Biocomplexity Grant (OCE-0119976), International Society for Reef Studies/Ocean Conservancy Fellowship, Khalid bin Sultan Living Oceans Foundation, and Project Aware, which enabled the project to be completed. The Keys Marine Laboratory supplied hours of boat support. The Fulbright-Department of Agriculture Philippines Scholarship and Maytag Fellowship provided for A.T.Y.'s support during her PhD. The University of the Philippines Office of the Vice Chancellor for Research and Development supplied additional support to A.T.Y. during the writing of this manuscript for publication.

\section{LITERATURE CITED}

Beach KS, Borgeas HB, Nishimura NJ, Smith CM (1997) In vivo absorbance spectra and the ecophysiology of reef macroalgae. Coral Reefs 16:21-28

Beach K, Walters L, Vroom P, Smith C, Coyer J, Hunter C (2003) Variability in the ecophysiology of Halimeda spp. (Chlorophyta, Bryopsidales) on Conch Reef, Florida Keys, USA. J Phycol 39:633-643

Beach KS, Walters LJ, Borgeas HB (2006) Irradiance and nutrient limitation of Dicytota spp. populations on Conch Reef, Florida Keys, USA. J Exp Mar Biol Ecol 329:101-112

Beaver CR, Jaap WC, Callahan MK, Kidney J and others (2006) U.S. EPA / FKNMS coral reef evaluation and monitoring project. U.S. Department of Commerce, National Oceanic and Atmospheric Administration, National Ocean Service, Office of National Marine Sanctuaries, Florida Keys National Marine Sanctuary, Marathon, FL

Bell AD, Tomlinson PB (1980) Adaptive architecture in rhizomatous plants. Bot J Linn Soc 80:125-160

Benedetti-Cecchi L, Bertocci I, Vaselli S, Maggi E (2006) Morphological plasticity and variable spatial patterns in different populations of the red alga Rissoella verrucosa. Mar Ecol Prog Ser 315:87-98

Biber PD (2002) The effects of environmental stressors on the dynamics of three functional groups of algae in Thalassia testudinum habitats of Biscayne Bay, Florida: a modeling approach. PhD thesis, University of Miami

Blanchette CA (1997) Size and survival of intertidal plants in response to wave action: a case study with Fucus gardneri. Ecology 78:1563-1578

Boller ML, Carrington E (2006) In situ measurements of hydrodynamic forces imposed on Chondrus crispus Stackhouse. J Exp Mar Biol Ecol 337:159-170

Boyer JN, Jones RD (2004) FY2004 annual report of the water quality monitoring project. Southeast Environmental Research Center, Florida International University, Miami, FL

Bradshaw AD (1965) Evolutionary significance of phenotypic plasticity in plants. Adv Genet 13:115-155

> Bruno JF, Sweatman H, Precht WF, Selig ER, Schutte VGW
(2009) Assessing evidence of phase shifts from coral to macroalgal dominance on coral reefs. Ecology 90: 1478-1484

Cain ML, Dudle DA, Evans JP (1996) Spatial models of foraging in clonal plant species. Am J Bot 83:76-85

> Carpenter RC (1986) Partitioning herbivory and its effects on coral reef algal communities. Ecol Monogr 56:345-364

Carrington E (1990) Drag and dislodgment of an intertidal macroalga: consequences of morphological variation in Mastocarpus papillatus Kuetzing. J Exp Mar Biol Ecol 139: $185-200$

Chiappone M, Sullivan KM (1997) Rapid assessment of reefs in the Florida Keys: results from a synoptic survey. Proc 8th Int Coral Reef Symp, Panama, p 1509-1514

Collado-Vides L (2002) Morphological plasticity of Caulerpa prolifera (Caulerpales, Chlorophyta) in relation to growth form in a coral reef lagoon. Bot Mar 45:123-129

Cronin G, Hay ME (1996) Induction of seaweed chemical defenses by amphipod grazing. Ecology 77:2287-2301

de Kroon H, Hutchings MJ (1995) Morphological plasticity in clonal plants: the foraging concept reconsidered. J Ecol 83:143-152

$>$ de Kroon H, Huber H, Stuefer JF, van Groenendael JM (2005) A modular concept of phenotypic plasticity in plants. New Phytol 166:73-82

Diaz-Pulido G, Villamil L, Almanza V (2007) Herbivory effects on the morphology of the brown alga Padina boergesenii (Phaeophyta). Phycologia 46:131-136

Gaillard J, L'Hardy-Halos MT, Pellegrini L (1986) Morphogenesis of Dictyota dichotoma (Huds.) Lamouroux (Phaeophyta). II. Ontogeny of thalli and ultrastructure of different cell types. Phycologia 25:340-357

Gardner TA, Cote IM, Gill JA, Grant A, Watkinson AR (2003) Long-term region-wide declines in Caribbean corals. Science 301:958-960

Hader DP, Porst M, Herrmann H, Schafer J, Santas R (1996) Photoinhibition in the Mediterranean green alga Halimeda tuna Ellis et Sol measured in situ. Photochem Photobiol 64:428-434

Halle F (1986) Modular growth in seed plants. Philos Trans R Soc Lond B Biol Sci 313:77-87

Hanisak MD, Littler DS, Littler MM (1988) Significance of macroalgal polymorphism: intraspecific tests of the functional-form model. Mar Biol 99:157-165

> Haring RN, Carpenter R (2007) Habitat-induced morphological variation influences photosynthesis and drag on the marine macroalga Pachydictyon coriaceum. Mar Biol 151: 243-255

Harper J (1985) Modules, branches, and capture of resources. In: Jackson J, Buss L, Cook R (eds) Population biology and evolution of clonal organisms. Yale University Press, New Haven, CT, p 1-34

Haus BK, Wang JD, Martinez-Pedraja J, Smith N (2004) Southeast Florida Shelf circulation and volume exchange, observations of km-scale variability. Estuar Coast Shelf Sci 59:277-294

> Hay ME (1981) The functional morphology of turf-forming seaweeds: persistence in stressful marine habitats. Ecology 62:739-750

Hay ME (1986) Functional geometry of seaweeds: ecological consequences of thallus layering and shape in contrasting light environments. In: Givnish TJ (ed) On the economy of plant form and function. Cambridge University Press, New York, NY, p 635-666

Herren LW, Walters LJ, Beach KS (2006) Fragment generation, survival, and attachment of Dictyota spp. at Conch Reef in the Florida Keys, USA. Coral Reefs 25:287-295 
Hillis-Colinvaux L (1980) Ecology and taxonomy of Halimeda: primary producer of coral reefs. Adv Mar Biol 17:1-327

Hutchings MJ (1988) Differential foraging for resources, and structural plasticity in plants. Trends Ecol Evol 3:200-204

- Hutchings MJ, Wijesinghe DK (1997) Patchy habitats, division of labour and growth dividends in clonal plants. Trends Ecol Evol 12:390-394

Jackson JBC, Coates AG (1986) Life cycles and evolution of clonal (modular) animals. Philos Trans R Soc Lond B Biol Sci 313:7-22

Koehl MAR (1986) Seaweeds in moving water: form and mechanical function. In: Givnish TJ (ed) On the economy of plant form and function. Cambridge University Press, New York, NY, p 603-634

Koehl MAR, Alberte RS (1988) Flow, flapping and photosynthesis of Nereocystis luetkeana: a functional comparison of undulate and flat blade morphologies. Mar Biol 99: 435-444

Koehl MAR, Wainwright SA (1977) Mechanical adaptations of a giant kelp. Limnol Oceanogr 22:1067-1071

Kooistra W, Verbruggen H (2005) Genetic patterns in the calcified tropical seaweeds Halimeda opuntia, H. distorta, $H$. hederacea, and H. minima (Bryopsidales, Chlorophyta) provide insights in species boundaries and interoceanic dispersal. J Phycol 41:177-187

Lewis SM, Norris JN, Searles RB (1987) The regulation of morphological plasticity in tropical reef algae by herbivory. Ecology 68:636-641

Lirman D, Biber P (2000) Seasonal dynamics of macroalgal communities of the Northern Florida Reef Tract. Bot Mar 43:305-314

Littler MM, Littler DS (1980) The evolution of thallus form and survival strategies in benthic marine macroalgae: field and laboratory tests of a functional form model. Am Nat 116:25-44

Littler DS, Littler MM (2000) Caribbean reef plants. Offshore Graphics, Washington, DC

Lovett-Doust L (1981) Population dynamics and local specialization in a clonal perennial (Ranunculus repens). I. The dynamics of ramets in contrasting habitats. J Ecol 69: $743-755$

Lubchenco J, Gaines SD (1981) A unified approach to marine plant-herbivore interactions. I. Populations and communities. Annu Rev Ecol Syst 12:405-437

Luke S, Cioffi-Revilla C, Panait L, Sullivan K, Balan G (2005) MASON: a multi-agent simulation environment. Simulation 81:517-527

Monro K, Poore AGB (2004) Selection in modular organisms: is intraclonal variation in macroalgae evolutionary important? Am Nat 163:564-578

Monro K, Poore AGB (2005) Light quantity and quality induce shade-avoiding plasticity in a marine macroalga. J Evol Biol 18:426-435

Monro K, Poore A, Brooks R (2007) Multivariate selection

Editorial responsibility: Charles Birkeland,

Honolulu, Hawaii, USA shapes environment-dependent variation in the clonal morphology of a red seaweed. Evol Ecol 21:765-782

Monsi M, Uchijimia Z, Oikawa T (1973) Structure of foliage canopies and photosynthesis. Annu Rev Ecol Syst 4: 301-327

Paddack MJ (2005) Herbivorous coral reef fishes in a changing ecosystem. PhD dissertation, University of Miami, FL

Padilla DK, Allen BJ (2000) Paradigm lost: reconsidering functional form and group hypotheses in marine ecology. J Exp Mar Biol Ecol 250:207-221

Porter JW, Kosmynin V, Patterson KL, Porter KG and others (2002) Chapter 27. Detection of coral reef change by the Florida Keys coral reef monitoring project. In: Porter JW, Porter KG (eds) The Everglades, Florida Bay and coral reefs of the Florida Keys: an ecosystem sourcebook. CRC Press, Boca Raton, FL, p 749-769

Smith JE, Smith CM, Vroom PS, Beach KL, Miller S (2004) Nutrient and growth dynamics of Halimeda tuna on Conch Reef, Florida Keys: possible influence of internal tides on nutrient status and physiology. Limnol Oceanogr 49:1923-1936

Steneck RE, Dethier MN (1994) A functional group approach to the structure of algal-dominated communities. Oikos 69:476-498

> Sutherland WJ, Stillman RA (1988) The foraging tactics of plants. Oikos 52:239-244

> Tuomi J, Vuorisalo T (1989) What are the units of selection in modular organisms? Oikos 54:227-233

> Van Alstyne KL (1989) Adventitious branching as a herbivore-induced defense in the intertidal brown alga Fucus distichus. Mar Ecol Prog Ser 56:169-176

Vroom PS (2001) Natural history and reproductive strategies of tropical reef algae, with an emphasis on the green algal order Bryopsidales and the genus Halimeda. PhD dissertation, University of Hawai'i, HI

Vroom PS, Smith CM, Coyer JA, Walters LJ, Hunter CL, Beach KS (2003) Field biology of Halimeda tuna (Bryopsidales, Chlorophyta) across a depth gradient: comparative growth, survivorship, recruitment, and reproduction. Hydrobiologia 501:149-166

> Walters LJ, Smith CM, Coyer JA, Hunter CL, Beach KS, Vroom PS (2002) Asexual propagation in the coral reef macroalga Halimeda (Chlorophyta, Bryopsidales): production, dispersal and attachment of small fragments. J Exp Mar Biol Ecol 278:47-65

Yñiguez AT (2007) Spatial dynamics in the growth and spread of Halimeda and Dictyota in Florida reefs: a simulation modeling approach. PhD dissertation, University of Miami, FL

> Yñiguez AT, McManus JW, De Angelis DL (2008) Allowing macroalgae growth forms to emerge: use of an agentbased model to understand the growth and spread of macroalgae in Florida coral reefs, with emphasis on Halimeda tuna. Ecol Modell 216:60-74

Submitted: June 29, 2009; Accepted: April 27, 2010

Proofs received from author(s): July 21, 2010 